Известия вузов России. Радиоэлектроника. 2020. Т. 23, № 5. С. 57-62 Journal of the Russian Universities. Radioelectronics. 2020, vol. 23, no. 5, pp. 57-62

Quantum, Solid-state, Plasma and Vacuum Electronics

Original article

https://doi.org/10.32603/1993-8985-2020-23-5-57-62

\title{
Optimization and Fabrication of Heterojunction Silicon Solar Cells Using an Experimental-Industrial Facility AK-1000 Inline
}

\author{
Nikolay A. Chuchvaga ${ }^{1,2}$, Julius Schulze ${ }^{3}$, Vassiliy V. Klimenov ${ }^{1,2,4}$, Kairat S. Zholdybayev',

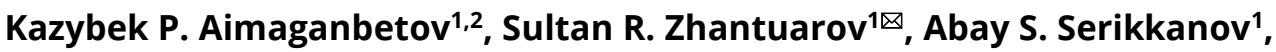 \\ Eugeny I. Terukov ${ }^{5,6}$, Serekbol Zh. Tokmoldin ${ }^{2,4}$, Nurlan S. Tokmoldin ${ }^{1,7}$ \\ ${ }^{1}$ Satbayev University, Institute of Physics and Technology, LLP, Almaty, Kazakhstan \\ ${ }^{2}$ Scientific-Production Center of Agricultural Engineering, LLP \\ ${ }^{3}$ Meyer Burger (Germany) AG, Germany \\ ${ }^{4}$ RDC SiTech, LLP, Almaty, Kazakhstan \\ ${ }^{5}$ A.F. Ioffe Physical-Technical Institute, St Petersburg, Russia \\ ${ }^{6}$ R\&D Center for Thin-Film Technologies in Energetics at A.F. Ioffe Physical-Technical Institute, \\ St Petersburg, Russia \\ ${ }^{7}$ University of Potsdam, Potsdam, Germany (currently) \\ stokmoldin@mail.ru
}

\begin{abstract}
Introduction. Heterojunction silicon solar cells represent one of the most promising directions for the development of solar photovoltaics. This is due to both their high power conversion efficiency and reasonable likelihood for further growth in performance, as well as good commercial potential of this technology, which relies on a transition from conventional diffusion-based processes to thin film deposition.

Aim. The paper describes results of optimization and fabrication of heterojunction silicon solar cells using the AK-1000 inline tool, adapted for processing of 6-inch wafers.

Materials and methods. In the manufacturing of solar cells, crystalline silicon wafers were subjected to wet chemical processes, and then electron, hole, and intrinsic types of conductivity of the layers based on amorphous silicon were deposited by plasma-chemical deposition. Precipitation of oxide transparent conductive layers was carried out by magnetron sputtering. To optimize the processes of obtaining solar cells, measurements of the reflection coefficient, of lifetime of minority carriers, and of current - voltage characteristics were used.

Results. As a result of the work, heterojunction solar cells were obtained in a laboratory in Kazakhstan with an efficiency of $20 \%$ without using of traditional diffusion processes for solar cells manufacturing.

Conclusions. The output parameters associated with light conversion efficiency demonstrate the possibility of further optimization of the parameters affecting the performance of heterojunction solar cells.
\end{abstract}

Keywords: heterojunction, silicon, solar cell, power conversion efficiency

For citation: Chuchvaga N. A., Schulze J., Klimenov V. V., Zholdybayev K. S., Aimaganbetov K. P., Zhantuarov S. R., Serikkanov A. S., Terukov E. I., Tokmoldin S. Zh., Tokmoldin N. S. Optimization and Fabrication of Heterojunction Silicon Solar Cells Using an Experimental-Industrial Facility AK-1000 Inline. Journal of the Russian Universities. Radioelectronics. 2020, vol. 23, no. 5, pp. 57-62. doi: 10.32603/1993-8985-2020-23-5-57-62

Acknowledgements. The authors acknowledge the funding support of the Ministry of Education of Science of the Republic of Kazakhstan within projects AP05133645, BR05236498, 0355-18-GK, AP05133651. The solar cell fabrication facility was built in the framework of the purpose-funding program 0.0652 .

Conflict of interest. The authors declare the absence of the conflict of interests.

Submitted 25.04.2020; accepted 05.10.2020; published online 25.11.2020

(c) Chuchvaga N. A., Schulze J., Klimenov V. V., Zholdybayev K. S., Aimaganbetov K. P., Zhantuarov S. R., Serikkanov A. S., Terukov E. I., Tokmoldin S. Zh., Tokmoldin N. S., 2020

Контент доступен по лицензии Creative Commons Attribution 4.0 License 
Известия вузов России. Радиоэлектроника. 2020. Т. 23, № 5. С. 57-62

Journal of the Russian Universities. Radioelectronics. 2020, vol. 23, no. 5, pp. 57-62

Introduction. Being the second most abundant chemical element in the earth crust, superseded by only oxygen, silicon is poised to dominate the field of large-scale terrestrial photovoltaics through years to come [1,2]. Among the silicon-based photovoltaic devices, the highest power conversion efficiency is currently demonstrated by heterostructured solar cells employing a semiconductor junction between crystalline and amorphous silicon. The technology of formation of such a heterojunction relies on plasma chemical vapor deposition of thin films of hydrogenated silicon $(\mathrm{a}-\mathrm{Si}: \mathrm{H})$ onto a monocrystalline silicon wafer (c-Si). This combination enables to obtain solar cells with record power conversion efficiencies exceeding $26 \%$ [3-5]. One of the confirmations of the high promise of this technology is its successful commercialization in the Commonwealth of the Independent States (CIS) [6, 7]. Further expansion of this technology is linked to demonstration of the industrial capability of the heterojunction silicon cell technology and its expansion to various parts of the world.

A monocrystalline silicon wafer is the main component for photovoltaic devices. Upon formation of the semiconductor junction, high-quality passivation of the wafer surface is required to reduce surface recombination of the charge carriers. The surface lifetime $\tau_{s}$ of minority carriers in a wafer with thickness $W$, diffusion coefficient $D$ and surface recombination rate $S$ can be determined from the following expression:

$$
\tau_{s}=\frac{W}{2 S}+\frac{1}{D}\left(\frac{W}{\pi}\right)^{2},
$$

where both sides of the wafer are considered to be identical. The effective (measured) lifetime of the carriers $\tau_{\text {ef }}$ is obtained via

$$
\frac{1}{\tau_{\mathrm{ef}}}=\frac{1}{\tau_{b}}+\frac{1}{\tau_{s}},
$$

where $\tau_{b}$ is the bulk lifetime, which depends on the quality and purity of initial silicon ingots used for slicing of the wafers. The use of intrinsic amorphous hydrogenated silicon (i-a-Si:H) for passivation of crystalline silicon demonstrates the possibility of significant improvement in the lifetime of minority carriers in the wafer $[8,9]$. This represents an important factor for achieving high power conversion efficiencies demonstrated by heterojunction silicon solar cells. This paper describes the results of optimization and fabrication of a heterojunction silicon solar cell with a power conversion efficiency of $20 \%$.

Experimental methods. The process of fabrication of heterojunction silicon solar cells has been reported previously elsewhere [10]. At the first stage, wet chemical treatment of crystalline wafers comprising a variety of operations targeting removal of surface contaminants and wafer texturing. During the process, the wafers were sequentially immersed into caustic and acidic solutions and rinsed with water to conduct the processes of saw damage etching, texturing, oxidation and oxide layer removal. Deionized water with resistivity of $1 \ldots 2 \mathrm{M} \Omega \cdot \mathrm{cm}$, measured directly in rinsing baths, was employed for cleaning and texturing. Following removal of the oxide layer, the wafers were loaded into a plasma chemical deposition chamber for coating with intrinsic amorphous silicon and amorphous silicon doped with boron (B) and phosphorous $(\mathrm{P})$ impurities, utilizing, respectively, monosilane $\left(\mathrm{SiH}_{4}\right)$, trimethylborane $\left(\mathrm{B}\left(\mathrm{CH}_{3}\right)_{3}\right)$ and phosphine $\left(\mathrm{PH}_{3}\right)$ as process gases. Further, indium tin-oxide transparent electrodes were deposited on both sides of the samples. Wafer metallization was performed using the DEK Eclipse tool. Minority carrier lifetimes, reflectivity and current-voltage characteristics were measured using the Sinton WCT-120, PV Measurements QEX10 and PV Measurements IV$16 \mathrm{~L}$ tools, respectively.

Results and Discussion. Texturing of the silicon wafers is performed in order to reduce their reflectivity and enhance optical absorption. Table 1 shows the reflectivity values of a non-textured wafer, as well as the wafers subjected to the texturing process at various concentrations of the etching agent.

Table 1. Dependence of reflectivity of the silicon wafer samples $(R)$ at optical wavelength of $600 \mathrm{~nm}$ on concentration of the etching agent $(C)$ following texturing

\begin{tabular}{|c|c|}
\hline$C, \mathrm{ml} / \mathrm{l}$ & $R, \%$ \\
\hline Initial wafer & 39.0 \\
\hline 6 & 17.4 \\
\hline 8 & 15.5 \\
\hline 10 & 13.0 \\
\hline 12 & 12.4 \\
\hline
\end{tabular}

It is evident, that the reflectivity is significantly reduced with the etchant concentration, however above $10 \mathrm{ml} / 1$ the rate of reduction in reflectivity with concentration slows down significantly. Surface images of the initial and textured wafers obtained by means of scanning electron microscopy (SEM), are shown in Fig. 1. 
Известия вузов России. Радиоэлектроника. 2020. Т. 23, № 5. С. 57-62 Journal of the Russian Universities. Radioelectronics. 2020, vol. 23, no. 5, pp. 57-62

The size of the resulting pyramids is approximately $5 \mu \mathrm{m}$, the concentration of the etching agent is $12 \mathrm{ml} / \mathrm{l}$, and the corresponding reflectance is $12 \%$. Similar results were obtained in [11], where for

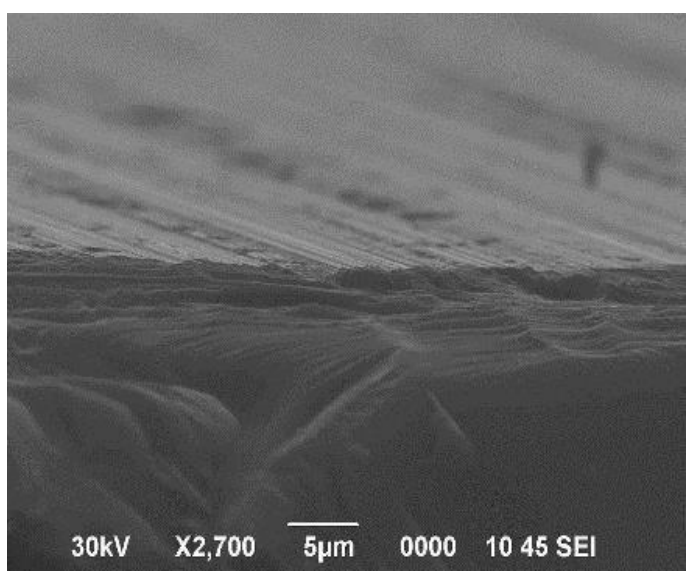

$a$

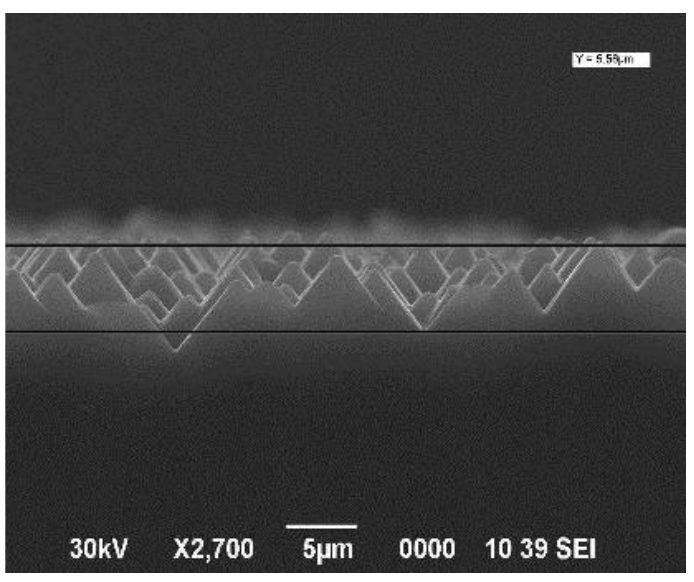

$b$

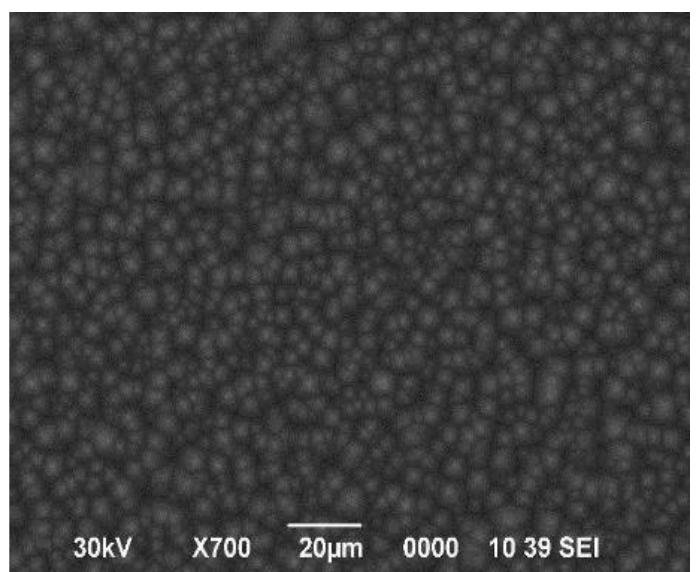

$c$

Fig. 1. Surface SEM images of the samples: $a-$ an initial untreated wafer (top-side view);

$b$ - following texturing at the etching agent concentration of $12 \mathrm{ml} / \mathrm{l}$ (side view);

$c$ - following texturing at the etching agent concentration of $12 \mathrm{ml} / \mathrm{l}$ (top view) pyramids of $5 \mu \mathrm{m}$ the reflection coefficient varied in close values of approximately $12.5 \ldots 19 \%$ at the incident light wavelengths of 400,500,600, and $700 \mathrm{~nm}$. It also notes that usually a reflection coefficient of $14 \ldots 15 \%$ is typical for pyramids with sizes of $2 \ldots 8 \mu \mathrm{m}$. In another work [12] by our team, textured samples with the lowest reflectance of the order of $12 \ldots 13 \%$ were obtained with a pyramid base of $5 \mu \mathrm{m}$.

Table 2 presents the results of minority carrier lifetime measurements in monocrystalline silicon wafers following the deposition of intrinsic, as well as n- and pdoped amorphous silicon layers on both sides.

The measured lifetime values correlate with Table 2. Minority carrier lifetimes in a monocrystalline silicon wafer following passivation with intrinsic amorphous silicon

\begin{tabular}{|c|c|}
\hline di, nm & $\tau, \mu \mathrm{s}$ \\
\hline 0 & 50 \\
\hline 11.6 & 656 \\
\hline 13.4 & 1505 \\
\hline 16.4 & 1775 \\
\hline
\end{tabular}

the results of other authors and indirectly confirm the results of computer simulations on the influence of amorphous layer thickness on solar cell output parameters, in particular, the open-circuit voltage $[13,14]$. It must be noted that, according to our preliminary study, the optimal thickness of the intrinsic amorphous silicon layers in the heterojunction cell is around $10 \mathrm{~nm}$, as higher thicknesses result in reduction in the short-circuit current and, consequently, power conversion efficiency due to the growth in the device series resistance [15].

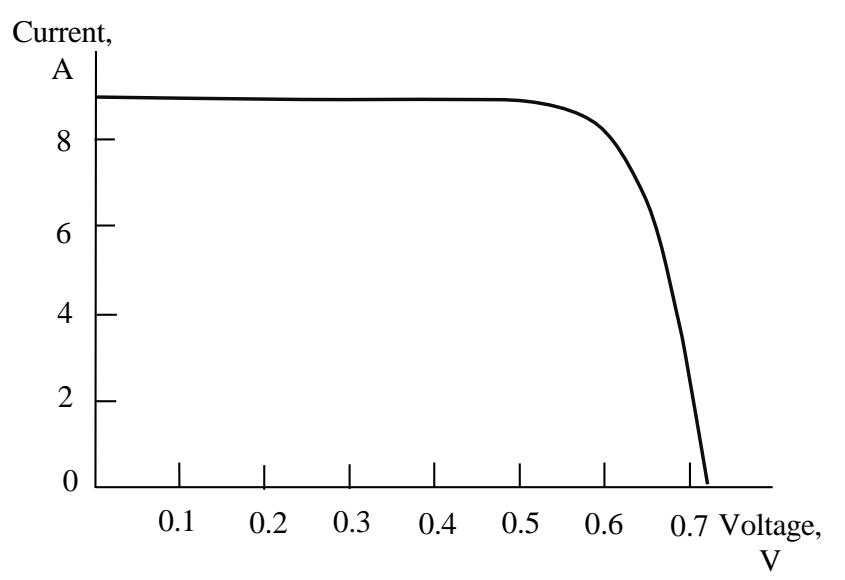

Fig. 2. Illuminated current-voltage characteristic of the fabricated photovoltaic cell 
Известия вузов России. Радиоэлектроника. 2020. Т. 23, № 5. С. 57-62

Journal of the Russian Universities. Radioelectronics. 2020, vol. 23, no. 5, pp. 57-62

Fig. 2 demonstrates the current-voltage characteristic of the fabricated photovoltaic cell.

Output cell parameters are given in Table 3.

Table 3. Output characteristics of the fabricated photovoltaic cell

\begin{tabular}{|c|c|c|c|}
\hline$\eta, \%$ & $F F, \%$ & $V_{\mathrm{OC}}, \mathrm{V}$ & $I_{\mathrm{SC}}, \mathrm{A}$ \\
\hline 20.00 & 75.92 & 0.721 & 8.93 \\
\hline
\end{tabular}

The efficiency of the device exceeds $20 \%$ at the open-circuit voltage of $720 \mathrm{mV}$, which is somewhat lower than the conventional values for this class of solar cells, showing the potential for further growth in power conversion efficiency upon optimization of fabricating conditions and an improvement in the quality of silicon wafer surface passivation.
Conclusion. This paper demonstrates the technological sequence and results of fabricating heterojunction silicon solar cells based on the semiconductor junction between crystalline and amorphous silicon. The influence of concentration of the etching agent on reflectivity of textured wafers, as well as the impact of thickness of intrinsic amorphous silicon on its surface passivation are investigated. Output parameters of the fabricated cell with efficiency exceeding $20 \%$ demonstrate the possibility of further optimization. Nevertheless, the obtained result, according to the available data, is a record for a solar cell whose main fabrication steps have been performed within Kazakhstan. It also shows the simplicity and safety of the heterojunction technology, which is based on deposition of thin films of semiconductor materials, rather than conventional diffusion-based processes.

\section{Author's contributions}

Nikolay A. Chuchvaga, thin-film deposition, writing.

Julius Schulze, process support, thin-film deposition.

Vassiliy V. Klimenov, process support, editing.

Kairat S. Zholdybayev, thin-film deposition, writing.

Kazybek P. Aimaganbetov, thin-film deposition, analysis.

Sultan R. Zhantuarov, wet etching, writing.

Abay S. Serikkanov, analysis, administration.

Eugeny I. Terukov, analysis, editing.

Serekbol Zh. Tokmoldin, project supervision, analysis, editing.

Nurlan S. Tokmoldin, conceptualization, wet etching, writing.

\section{References}

1. Battaglia C., Cuevas A., De Wolf S. High-efficiency crystalline silicon solar cells: status and perspectives. Energy Environ. Sci. 2016, vol. 9, iss. 5, pp. 1552-76. doi: 10.1039/C5EE03380B

2. Andreani L. C., Bozzola A., Kowalczewski P., Liscidini M., Redorici L. Silicon solar cells: toward the efficiency limits. Advances in Physics: X. 2019, vol. 4, iss. 1, p. 1548305. doi: $10.1080 / 23746149.2018 .1548305$

3. Yoshikawa K., Kawasaki H., Yoshida W., Irie T., Konishi K., Nakano K., Uto T., Adachi D., Kanematsu M., Uzu H., Yamamoto K. Silicon heterojunction solar cell with interdigitated back contacts for a photoconversion efficiency over 26 \%. Nature Energy. J. Art. 2017, vol. 2, iss. 5. doi: 10.1038/nenergy.2017.32

4. Haschke J., Dupré O., Boccard M., Ballif C. Silicon heterojunction solar cells: Recent technological development and practical aspects-from lab to industry. Sol. Energy Mater Sol. Cells. 2018, vol. 187, pp. 140-53. doi: 10.1016/j.solmat.2018.07.018

5. Liu Y., Li Y., Wu Y., Yang G., Mazzarella L., ProcelMoya P., Tamboli A. C., Weber K., Boccard M., Isabella O.,
Yang X. High-Efficiency Silicon Heterojunction Solar Cells: Materials, Devices and Applications. Mater. Sci. Eng. R Rep. 2020, vol. 142, p. 100579. doi: 10.1016/j.mser.2020.100579

6. Terukov E., Kosarev A., Abramov A., Malchukova E. From $11 \%$ Thin Film to 23 \% Heterojunction Technology (HJT) PV Cell: Research, Development and Implementation Related $1600 \times 1000$ mm PV Modules in Industrial Production. Book Chapter in: Zaidi B. (ed) Solar Panels and Photovoltaic Materials. 2018. doi: 10.5772/intechopen.75013

7. Abramov A. S., Andronikov D. A., Abolmasov S. N., Terukov E. I. Silicon Heterojunction Technology: A Key to High Efficiency Solar Cells at Low Cost. Book Chapter in: Petrova-Koch V., Hezel R., Goetzberger A. (eds) High-Efficient Low-Cost Photovoltaics. Springer Series in Optical Sciences. 2020, vol. 140, pp. 113-132. Springer, Cham. doi: 10.1007/978-3-030-22864-4_7

8. Pankove J. I., Tarng M. L. Amorphous silicon as a passivant for crystalline silicon. Applied Physics Lett. 1979, vol. 34, iss. 2, pp. 156-157. doi: 10.1063/1.90711

9. Herasimenka S. Y. Large area ultrapassivated silicon solar cells using heterojunction carrier collectors. 
Известия вузов России. Радиоэлектроника. 2020. Т. 23, № 5. С. 57-62 Journal of the Russian Universities. Radioelectronics. 2020, vol. 23, no. 5, pp. 57-62

Doctoral Dis. Arizona State University. USA, 2013, 233 p.

10. De Wolf S., Descoeudres A., Holman Z. C., Ballif C. High-efficiency Silicon Heterojunction Solar Cells: A Review. 2012, vol. 2, iss. 1, pp. 7-24. doi: 10.1515/green-2011-0018

11. Han Y., Yu X., Wang D., \& Yang D. Formation of Various Pyramidal Structures on Monocrystalline Silicon Surface and Their Influence on the Solar Cells. J. of Nanomaterials. 2013, vol. 2013, pp. 1-5. doi: 10.1155/2013/716012

12. Chuchvaga N. A., Kislyakova N. M., Tokmoldin N. S., Rakymbetov B. A., Serikkanov A. S. Problemy pri ispol'zovanii travitelya KOH-IPA dlya teksturirovaniya kremnievyh plastin [Problems when using $\mathrm{KOH}-I \mathrm{PA}$ Etchant for silicon wafer texturing]. Technical Physics Journal. 2020, vol. 90, iss. 10, pp. 1758-1763. doi: 10.21883/JTF.2020.10.49810.431-19 (In Russ.)
13. Yao Y., Xiao S., Zhang X., Gu X. Simulation optimizing of n-type HIT solar cells with AFORS-HET. J. Modern Physics Letters B. 2017, vol. 31, iss. 19-21, 1740025 p. doi: 10.1142/S0217984917400255

14. Keshuov S., Tokmoldin N., Chuchvaga N., Tokmoldin S., Isova A. An algorithm for optimization of heterojunction silicon solar cells by ranking of fabrication parameters influencing their efficiency. J. Ekoloji. 2019, vol. 28 , iss. 108 , pp. $2681-2692$.

15. Chuchvaga N. A., Zhilina D. V., Zhantuarov S. R., Tokmoldin S. Zh., Terukov E. I., Tokmoldin N. S. Study and optimization of heterojunction silicon solar cells. J. Phys. Conf. Series. Mar. 2018, vol. 993, pp. 1-7. doi: $10.1088 / 1742-6596 / 993 / 1 / 012039$

\section{Information about the authors}

Nikolay A. Chuchvaga, $\mathrm{PhD}$ (2019), Senior Researcher at the Institute of Physics and Technology LLP and MNS LLP Scientific and Production Center of Agroengineering, Almaty, Kazakhstan. Senior lecturer at al-Farabi Kazakh National University and the Kazakh-German University. From 2010 to 2014, he was an employee, and also wrote bachelor's and master's theses at the P.I. Ioffe RAS. He completed his PhD thesis at the P.I. Ioffe RAS (Russia) and IPT LLP (Kazakhstan). Area of expertise: solid state physics, photonics and electronics, semiconductor devices, radiation resistance of materials, silicon carbide, mathematical physics.

Address: Satbayev University, Institute of Physics and Technology, 11 Ibragimov St., 050032, Almaty, Kazakhstan E-mail: nikolay.chuchvaga @gmail.com https://orcid.org/0000-0003-4417-4996

Julius Schulze, Master of science, Technologist, Meyer Burger (Germany) Address: An der Baumschule 6-8, 09337 Hohenstein-Ernstthal, Germany E-mail: julius.schulze@meyerburger.com

Vassiliy V. Klimenov, Chief Technologist of the Physico-Technical Institute LLP and the Scientific and Production Center of Agroengineering LLP. Postgraduate studies - "Solid State and Condensed Matter Physics" Physics and Technology Institute 2006-2009. Area of expertise: technical physics, materials science, photovoltaics.

Address: Satbayev University, Institute of Physics and Technology, 11 Ibragimov St., 050032, Almaty, Kazakhstan E-mail: vasyly_vasyly@ rambler.ru https://orcid.org/0000-0001-6836-3033

Kairat S. Zholdybayev, Junior Researcher of the Satbayev University, Institute of Physics and Technology, LLP. Education: Master (Kazakh National University named after Al-Farabi, 2016, specialty - Nuclear Physic). After graduating from the master degree in 2016, he is engaged in research in the field of research of heterojunction silicon and perovskite solar cells at the Laboratory of Photoelectric Phenomena and Devices (LPNP). On this topic, he is preparing a thesis for the degree of Doctor of Philosophy PhD. Area of expertise: silicon solar cells, perovskites.

Address: Satbayev University, Institute of Physics and Technology, 11 Ibragimov St., 050032, Almaty, Kazakhstan E-mail: gaisin0510@gmail.ru

https://orcid.org/0000-0002-0208-9104

Kazybek P. Aimaganbetov, Researcher LLP "Physics and Technology Institute" and LLP "Research and Production Center of Agroengineering". Master 2017 (Technical Physics, KazNRTU named after Satpayev). At the moment he is studying under the $\mathrm{PhD}$ program. Area of expertise: photovoltaics, cryo-technologies.

Address: Satbayev University, Institute of Physics and Technology, 11 Ibragimov St., 050032, Almaty, Kazakhstan E-mail: a.k_012@mail.ru https://orcid.org/0000-0001-6367-9135

Sultan R. Zhantuarov, Junior Researcher of the Satbayev University, Institute of Physics and Technology, LLP. Education: Master (National Research Tomsk Polytechnic University, 2014, specialty - 011200, «Physics»). After graduating from master's degree in 2014 , he is engaged in research in the field of research of perovskite solar cells at the Laboratory of Photoelectric Phenomena and Devices. On this topic, he is preparing a PhD thesis. Area of expertise: nanopowders, photovoltaics, perovskites.

Address: Satbayev University, Institute of Physics and Technology, 11 Ibragimov St., 050032, Almaty, Kazakhstan E-mail: sultzhantuarov@mail.ru https://orcid.org/0000-0002-2467-0178 
Известия вузов России. Радиоэлектроника. 2020. Т. 23, № 5. С. 57-62

Journal of the Russian Universities. Radioelectronics. 2020, vol. 23, no. 5, pp. 57-62

Abay S. Serikkanov, Director of FTI LLP. Candidate of Physical and Mathematical Sciences, Chief Researcher of the Physico-Technical Institute LLP. Area of expertise: materials science, new materials, solid state physics, alternative and renewable energy sources.

Address: Satbayev University, Institute of Physics and Technology, 11 Ibragimov St., 050032, Almaty, Kazakhstan

E-mail: a.serikkanov@gmail.com

https://orcid.org/0000-0001-6817-9586

Eugeny I. Terukov, Dr. Sci. (Eng.) in Technical Sciences in the specialty of "Semiconductors and Dielectrics" (1996), Professor, Head of laboratory of Ioffe Physics and technical Institute, St Petersburg. The author of more than 400 scientific publications. Area of expertise: physics and technology of amorphous semiconductors, semiconductors devices.

Address: Ioffe Physics and Technical Institute, 26 Polytechnicheskaya St., 194021, St Petersburg, Russia

E-mail: eug.terukov@mail.ioffe.ru

https://orcid.org/0000-0002-4818-4924

Serekbol Zh. Tokmoldin, Dr. Sci. (Physics and Mathematics), Chief Researcher of the Research and Production Center of Agroengineering LLP, Director of Silica Metals LLP and RDC SiTech LLP, Almaty, Kazakhstan. Authored more than 40 publications in high-profile peer reviewed research journals. Area of expertise: solid state physics, alternative and renewable energy sources, photonics and electronics, semiconductor devices, radiation resistance of materials.

Address: Scientific-Production Center of Agricultural Engineering, 312 Raiymbek Ave., 050005, Almaty, Kazakhstan E-mail: stokmoldin@mail.ru https://orcid.org/0000-0003-0633-4733

Nurlan S. Tokmoldin, PhD in Organic Electronics (2011), at the time of preparing the manuscript Head of Laboratory of Photovoltaic Phenomena and Devices, Institute of Physics and Technology, Almaty (Kazakhstan). Currently, post-doctoral researcher at the University of Potsdam (Germany). Author over 40 research publications. Area of expertise: solar energy, renewables, low-temperature physics.

Address: Satbayev University, Institute of Physics and Technology, 11 Ibragimov St., 050032, Almaty, Kazakhstan E-mail: ntokmoldin@gmail.com

https://orcid.org/0000-0002-0663-0228 